\title{
Gender and Power in American Legislative Discourse
}

\author{
Laura R. Winsky Mattei \\ State University of New York at Buffalo
}

\begin{abstract}
In a modern democracy, all citizens theoretically are guaranteed an equal opportunity at political representation. This paper shows that democratic theory does not always hold in practice in the United States. Discourse analysis is applied to the language used in the 1990 hearings conducted by the U.S. Senate Committee on the Judiciary on the nomination of Judge David H. Souter to be Associate Justice of the Supreme Court. Results show that while women are noticeably present as witnesses in hearings, they are not treated on an equal footing with men. Women's access to the political debate is limited, because they are given proportionally less time to speak than male witnesses. Further, empirical measures indicate that the effectiveness of women's testimony is undermined by senators' responses. Although women utilize what is defined as masculine language to compete within a male-dominated institution, gendered expectations can prevent them from being treated as authoritative witnesses.
\end{abstract}

Studies of representation have documented the frequency with which women have begun to enter male-dominated arenas of American politics. Over time, the number of women elected to state legislatures has increased from about $8 \%$ in 1975 , to $21 \%$ of all legislators by 1993 . Women have moved up the political ladder to seats in Congress, as well; Congress was $4 \%$ female in 1975 and has been $11 \%$ female since the elections of 1994 (CAWP 1996). Numerous theorists expect female legislators to differ as a group from their male counterparts because of the effects of gender, or social constructions of what is feminine and masculine. The increasing diversity of legislative bodies thus has allowed scholars an opportunity to better explore the relevance of gender to legislative policy (e.g., Ford and Dolan 1996; Thomas 1994).

While the presence and policy priorities of women in public office are important components of gender-related research, effective representation of interests is a complex process that requires additional and varied analyses. In state legislatures that are at least $20 \%$ female, for example, women members are more likely to form distinct interests, giving higher priority to bills dealing with women, children, and families than do their male peers (Thomas 1994, 94). Such strategic concerns suggest the need to look further at gendered institutional prac-

An earlier version of this paper was presented at the annual meeting of the American Political Science Association, 1996. I would like to thank Lyn Kathlene, Phyllis Pease Chock, and Sue Thomas for their comments at various stages of this research. Finally, my thanks to Lisa K. Parshall for her invaluable research assistance with this project.

THE JOURNAL OF POLITICS, Vol. 60, No. 2, May 1998, Pp. 440-61

(C) 1998 by the University of Texas Press, P.O. Box 7819, Austin, TX 78713-7819 
tices that may differentially constrain the opportunities for leadership by women and men. Indeed, Kathlene's work (1994) extends the understanding of gender in this direction, demonstrating that interpersonal committee dynamics can work to the disadvantage of women state legislators.

This paper further broadens the study of representation by asssessing the ability of women to obtain representation as witnesses in congressional hearings. Historically, women's groups primarily have voiced their concerns in the hearing rooms of Congress to male committees (Mueller 1991, 25). Nevertheless, the activities of women in this national political sphere remain understudied. Hence, the empirical analysis below focuses on measuring the power of language in the interactions of senators and witnesses in recent hearings of the U.S. Senate Committee on the Judiciary. The primary objective of this research is to develop and test measures of the extent to which both men and women have access to legislative debate and are able to represent their views effectively. An explication of these measures and concepts is preceded by a review of a diverse literature on power, gatekeeping, gender, and communication.

\section{Power, Gender, and Gatekeeping}

Some have characterized the liberal ideology behind American politics - in which individualism, self-realization, and competition are central - as a model that is ill equipped to eradicate the subjugation of social groups in a democracy (Hooks 1987, 65-68). In a liberal framework, it is assumed that individual women who decide to break into previously all-male domains can compete with men and succeed; in other words, some believe we can just add some women to the political melting pot and stir (for a lengthier discussion, see Kelly and Duerst-Lahti 1995, 51-54). Such an ideology, however, overlooks the possibility that members of some groups are disadvantaged by the rules governing the exercise of power in society, rules that benefit the players who are already in a preferred position (Bachrach and Botwinick 1992, 59).

As Sapiro (1991) and Kenney (1996) explain, because American political institutions developed as male domains, these institutions are gendered, with men in the preferred position. ". . . [H]istorical experience has shown women that government is not a neutral tool that can be used equally to anyone's advantage;" the weak cannot be expected to have the same powers as the strong, because they do not have the same resources (Sapiro 1991, 174-75). Carrying Sapiro's argument one step further, Duerst-Lahti and Kelly (1995) point out that women who enter politics must "do so within ideological terms of masculine norms," and thereby are limited by our socially constructed images of gender. As their review of evidence shows, masculinity, or our social constructions of what is masculine, permeates politics and cultural definitions of leadership. Because male behavior typically forms the basis for masculinity, men can use gender power to maintain their predominance in the public sphere 
(Duerst-Lahti and Kelly 1995, 16-20). Whether a conscious practice or not, politics then operates to the advantage of one gender. As a result, even women who obtain formal positions of power may not be equal to men in the same position (Kelly and Duerst-Lahti 1995, 47).

Others have similarly recognized that few women rank among American political leaders, in part because men in power use their positions and resources to perpetuate their control and maintain women's outsider status (Costantini 1990, 748). This imbalance in gender power within institutions can extend to interpersonal relations; for example, gender affects who will be perceived as a leader, and whose arguments will be regarded as persuasive in debates or discussions (Kelly and Duerst-Lahti 1995, 59-60). Thus, one way in which a dominant group can maintain control is through the conscious or unconscious use of discourse. By discourse, Fairclough (1989) means the whole process of social interaction of which text is a part. He argues that the reproduction of power relations through language may be subtle and done without explicit recognition by the participants (or subjects). "Control over orders of discourse by institutional and societal power-holders is one factor in the maintenance of their power" (Fairclough 1989, $24,37)$. Persons with power of another sort (e.g., those elected to office) in a discourse may be "controlling and constraining the contributions of non-powerful participants" without even consciously thinking about it (Fairclough 1989, 46). The importance of words and images is further explicated by MacKinnon (1993): "Social inequality is substantially created and enforced-that is, donethrough words and images" (13). "Nothing has no content. Society is made of words, whose meanings the powerful control, or try to. At a certain point, when those who are hurt by them become real, some words are recognized as the acts that they are" (30). Words, then, are not "just words" devoid of consequences; they reflect and convey power.

\section{Gender and Communication Styles}

The potential impact of gatekeeping through discourse is compounded and most insidious when its exercise against members of a particular group is reinforced by coincidental style differences, such as gender differences. When communication differences coincide with one's social grouping(s), "the consequences of style differences work to the disadvantage of members of groups that are stigmatized in our society, and to the advantage of those who have the power to enforce their interpretations. This is the very kernel of the term and concept of 'gatekeeping"' (Tannen 1994a, 8). Those with formal positions of power win encounters in which there are style differences. "Examining the workings of conversational style in interaction can help explain how dominance is actually created in interaction" (10).

Research confirms that learned gender patterns are visible in the language that the sexes use and that language, in turn, can reflect and reinforce masculine speakers' social positions and power (Case 1994, 144-45). Such social power is 
manifested in a variety of contexts; Luttrell's work (1995) indicates that differential verbal treatment by educators on the basis of sex, race and class is easily perceived by students on the losing side of the social divide $(464,467-68)$. In part, gender differences result because women tend to have different purposes for communication than men. Men are likely to view verbal exchanges as contests to be won or lost, whereas women generally talk and construct knowledge to build connections, equality, and understanding (Case 1994, 149; Luttrell 1995, 433; Tannen 1990). ${ }^{1}$ Not coincidentally, the purpose of male communication is consistent with men's retention of established power in a competitive political system.

According to Carroll (1989), females are taught femininity, which means dependency, submissiveness, conformity, and passivity $(307,311)$. In keeping with this general characterization, a good deal of research has shown that women tend to talk less than men overall (Case 1994, 145; see Kollock, Blumstein, and Schwartz 1985, 35-36, for a review of the literature; Smith-Lovin and Brody 1989; and Tannen 1990, 75-76). However, behavior can be affected by the context in which persons are interacting. Edelsky's (1981) examination of interactions on a university committee shows that women interact as verbal equals with men when the setting for talking is informal and cooperative. When discourse is characterized by monologues where "turns" are well defined and the floor is to be won or lost, men participate at significantly higher levels than their female colleagues (Edelsky 1981, 415-16). This finding fits well with the gendered purposes of communication; if verbal exchanges are viewed as exchanges to be won, then masculine persons can be expected to obtain as much speaking time as possible.

Kathlene's recent work (1994) further addresses the possible interactions between sex, context, leadership and discourse in a legislative setting. Controlling for legislators' party, position, seniority, and interest in bills, she shows that men participate at higher rates and interrupt more in legislative committees. Even when they are elected legislators, "women . . . , despite their numerical and positional gains, may be seriously disadvantaged in committee hearings and unable to participate equally" (Kathlene 1994, 572-73).

As Kathlene notes, an additional indicator of dominance in conversation is the extent to which a person interrupts others. An interruption is an overlap in conversation that is used as a tactic of domination for regaining the floor, or access. Research in nonlegislative settings also indicates that men interrupt more than women (Kollock, Blumstein, and Schwartz 1985, 35; Smith-Lovin and Brody 1989, 424-25; Tannen 1994a, 55). ${ }^{2}$ Moreover, some studies have shown it is expected that men will interrupt more than women, or that interrupting is

\footnotetext{
${ }^{1}$ Unless otherwise noted, research subjects in studies referenced in this section are not political elites. The findings are relevant, however, because they attest to the overall cultural patterns and gender expectations that affect all women and men.

${ }^{2}$ However, Pearson, West, and Turner (1995) note that conclusions about gender and interruption are mixed, and the subject requires further research $(1995,133)$.
} 
perceived as a masculine trait (Pearson, West, and Turner 1995, 133; Tannen 1994b, 119, 170). Psychological studies show that women are judged to be more warm, gentle, kind, and passive than men; males are viewed as more aggressive, assertive, rational, or competent. (Huddy 1994, 171). Insofar as interruption can be viewed as assertive behavior, it may be something women are not expected to do; and when they do engage in the behavior, women may be judged negatively for it (Tannen 1994b, 170).

A final point about gendered communication is that it is related to issues of credibility and authority. As Kelly and Duerst-Lahti (1995) indicate, in part, one listens to and is persuaded by those who are perceived as leaders, and persuasiveness is something more likely belonging to the masculine gender. The legislative process basically is modeled on the American legal system in which witnesses are divided into two categories: ordinary versus expert. "Ordinary witnesses are not supposed to make inferences or interpretations on the basis of what they have directly experienced, i.e., they are not supposed to express opinions about it." This is because the purpose of a nonexpert is to present information that the powerful will interpret on their own. Expert witnesses, in contrast, are defined as having some training or experience that allows them to offer an opinion and interpret evidence in a way that is assumed to be reliable (Philips 1993, 254). If gender is a key variable in determining how individuals are treated, women may be perceived and treated as ordinary witnesses, regardless of their credentials. Indeed, research on the American legal process shows that women generally (whether witnesses or lawyers) are likely to be perceived in the category of persons who are not believable or credible (D'Lugin 1993; Hodgson and Pryor 1984). Past evidence from congressional hearings similarly shows that female participants were categorized along with children as representing what was "irrational and uncontrollable" as opposed to that which was "rational, deliberate, and market-driven" (Chock 1995, 174). ${ }^{3}$ Kathlene (1995b) reports that women in legislatures have to establish their credibility in the process of participation, whereas men are assumed to have it (7-8); "all else being equal, women are not as likely to be listened to as men, regardless of how they speak or what they say" (Tannen 1994b, 284).

A review of the literature shows that women may not be integrated easily into male-dominated institutions. Men may utilize their gendered power, consciously or unconsciously, to perpetuate masculine dominance. Interdisciplinary work suggests that one potential form of gatekeeping may be through the language used in verbal interactions; masculine communication is well suited for gatekeeping, given its emphasis on competition and holding the floor. I now turn to specific hypotheses about how gender may affect congressional hearings.

\footnotetext{
${ }^{3}$ Additionally, I am grateful to Carrie Tirado Bramen for noting the gender relevance of remarks that allege to define who or what is "reasonable, objective, or rational."
} 


\section{Congressional Hearings and Gender}

In addition to women's presence in democratic decision-making bodies, it is also important to ascertain their levels of access, and the effectiveness of women's participation in securing representation in all legislative processes. By access, I mean the quantity of women's participation in comparison to men's. In contrast, effectiveness refers to more qualitative measures of representation. In the context of a legislative hearing, a key component of effectiveness is witnesses' ability to receive legislators' consideration and to have testimony respected as credible or representing a valid view.

Given the literature on gender, gatekeeping, and language, testable hypotheses can be derived about the observable behavior of senators and witnesses in congressional hearings. The first two hypotheses concern access. First, it is expected that senators will reserve most speaking time for themselves in hearings. ${ }^{4}$ Also, in keeping with gendered patterns revealed in past research, the floor time used by a male witness will be greater, on average, than that by a female witness. In a masculine, competitive environment where holding the floor and winning is of pivotal importance, gendered power will place women, the feminine sex, at the greatest disadvantage, even though they have been invited to participate. Second, because senators in this study are male and also in the formal positions of power, they will do more of the interrupting overall than any other group; further, senators, if they are engaging in gatekeeping, are expected to interrupt women witnesses more frequently than they interrupt male witnesses. To the extent that witnesses interrupt other speakers, it is expected that men will do so more than women.

Third, it is hypothesized that the effectiveness of female witnesses, relative to their male counterparts, will be limited by senators' attempts to undermine the authority and credibility of women's testimony. Senators, influenced by gendered expectations and gatekeeping, will treat men as more authoritative and credible witnesses than women who testify, limiting the effectiveness of female witnesses. Specific operationalizations are outlined below.

Fourth, male witnesses should be more likely than female witnesses to testify in an expert or authoritative manner, thereby reinforcing senators' expectations that men are expert witnesses. In general, I am referring to rational testimony based on empirical evidence. As Chock (1995) observes, when numbers or tables were used in immigration hearings, for example, they had the aura of science. Science has an authority that can be used to make it seem that the numbers

\footnotetext{
${ }^{4}$ In analyses below, senators are all males, while the sex of witnesses varies. Based on past research, senators are expected to dominate the floor primarily because they are male. Variation in the sex composition of the committee would provide controls (see additional comments below). Nevertheless, an all-male committee more accurately replicates the conditions that women have had to face as witnesses. Further, before the potential impact of female senators can be evaluated, we need first to understand how male legislatures have functioned historically.
} 
represent an objective reality, that they are unambiguous, apolitical. "This understanding . . . presumed that science produces knowledge that is independent of the observer's social or cultural situation. Thus, these terms that suggested their origin in science enabled the speakers to place themselves above politics," without any concern for the fact that all the "experts" were upper-middle-class men (Chock 1995, 171). Hence, Chock's findings suggest that male senators value scientific testimony, but that only male witnesses offer such evidence.

The final hypothesis is the most exploratory of the paper. I hypothesize that if female witnesses adapt to a masculine environment by responding to challenges to their authority with competitive language, such as interruptions or scientific evidence, they will meet with limited success. In short, women are caught in what Jamieson (1995) classifies as a "double bind." If female witnesses exhibit feminine communication styles, they will have difficulties in asserting themselves in response to male behavior, which seeks to control the floor with regard to both quantity and content (Pearson, West, and Turner 1995, 94-96). The alternative for women is to adopt more masculine behaviors to fit in to the legislative setting; however, "if they adopt a more 'masculine' style, they are seen as abrasive" (Stewart and Clarke-Kudless 1993, 148). Although Jamieson (1995) argues that there are options that women can pursue to break these double binds (8), it remains unclear what these alternatives are.

\section{Data, Methods, and Operationalization}

Data for the analysis below are taken from the transcripts of the U.S. Senate Judiciary Committee's hearings on the nomination of David Souter to the Supreme Court. Supreme Court nominations are good opportunities for discourse analysis, because numerous witnesses are called to testify and are questioned by multiple senators. Under examination are the transcribed comments of 11 senators and 18 witnesses across 30 selected question periods on September 17-19, 1990 (see Table 1). ${ }^{5}$ Analyses are limited to interactive sections of the hearings and exclude the prepared opening statements of the witnesses. Controls are achieved by evaluating how a panel of witnesses is treated by multiple senators (holding the witnesses constant), and by holding constant the senator while varying the witnesses.

To the extent allowed, a deliberate effort was made to include female and male witnesses, witnesses who opposed and who favored Souter's confirmation, and senators from both parties. Senators' interactions with six panels are examined; in Table 1, panels 2 and 5 are all female, panel 3 is two-thirds female, and panel 4 includes one woman; the remaining witnesses are male. ${ }^{6}$

\footnotetext{
${ }^{5}$ I use the label "question period" to refer to that block of time given to each senator in the congressional hearing to talk with or question a panel of witnesses.

${ }^{6}$ The sex composition of the committee varied following the 1992 election, allowing for the possibility of comparative analyses of male and female senators. The most appropriate comparison would be with other hearings for nominees to the Supreme Court while Congress was still controlled by the
} 


\section{TABLE 1}

\section{List of Witnesses and Senators}

Panel 1: Judd Gregg, Governor of New Hampshire.

Questioning by Senators Humphrey (R), Heflin (D), Simon (D), and Biden (D).

Total words $=778$; average per speaker $=156$

Panel 2: Kate Michelman, executive director, National Abortion Rights Action League; Faye Wattleton, president, Planned Parenthood Federation of America.

Questioning by Senators Biden (D), Thurmond (R), Kennedy (D), Simpson (R), Heflin (D), and Specter $(R)$.

Total words $=8,989$; average per speaker $=1124$

Panel 3: Antonia Hernandez, president and general counsel, Mexican-American Legal Defense and Education Fund; Joseph L. Rauh Jr., general counsel, Leadership Conference on Civil Rights; Joan Bronk, president, National Council of Jewish Women.

Questioning by Senators Biden (D), Thurmond (R), and Kennedy (D).

Total words $=3,553$; average per speaker $=592$

Panel 4: Chuck Douglas, U.S. Congressman from New Hampshire; John Broderick, president, New Hampshire Bar Association; Steven J. McAuliffe, president-elect, New Hampshire Bar Association; Deborah Cooper, former deputy attorney general, New Hampshire.

Questioning by Senators Biden (D), Specter (R), Simon (D), Thurmond (R), Humphrey (R), Hatch (R), Simpson (R), and Kennedy (D).

Total words $=5,560$; average per speaker $=463$

Panel 5: Elizabeth Holtzman, comptroller, city of New York; Helen Neuborne, executive director, NOW Legal Defense and Education Fund; Gloria Allred, Los Angeles attorney; Molly Yard, president, National Organization for Women; Eleanor Curti Smeal, president, Fund for the Feminist Majority.

Questioning by Senators Biden (D), Thurmond (R), Hatch (R), Simpson (R), and Specter $(R)$. Total words $=10,599$; average per speaker $=1,060$

Panel 6: Wesley S. Williams Jr., Covington \& Burling, Washington, D.C.; Robert L. Beck, immediate past chair of the board and CEO, Mothers Against Drunk Driving; Robert L. Barr Jr., president, Southeastern Legal Foundation, Inc.

Questioning by Senators Thurmond ( $R$ ), Kennedy (D), DeConcini (D), Specter (R), and Grassley $(R)$. Total words $=3,090$; average per speaker $=386$

Panels from the U.S. Senate Judiciary Committee hearings on September 18-19, 1990, regarding David H. Souter's nomination to be Associate Justice of the Supreme Court

In order to measure the language of import, all statements made by senators and witnesses during an interactive question period were coded manually by a research assistant or the author. Code sheets were devised by the author to analyze one sentence at a time; each line on a code sheet records the number of words spoken in each sentence. Thus, to code for access, both the number of words spoken and the number of interruptions are counted for each speaker;

same party. However, in the recent nomination proceedings that meet these criteria, the two female committee members do not question any witnesses; consequently, no comparable data are yet available for hearings involving female senators. In any case, at best the committee has had one or two female members, and as Thomas (1994) notes, not even a membership of $25-30 \%$ female in a legislative chamber is enough of a critical mass to affect overall legislative practices and priorities (99). 
from there, percentages or rates are calculated for each participant. Measuring the effectiveness of the verbal interactions is a more lengthy process. Code sheets indicate whether each sentence contains a variable of interest. For reliability, some segments were coded twice; ${ }^{7}$ however, given the time-consuming nature of the work, not all coding could be replicated.

There are multiple empirical measures of the credibility of a legislative witness. One measure of challenge to authority is question type. When a senator asks difficult, empirical, analytical questions rather than opinion or factual questions, it is one way of testing a witness's authority. Distinguishing question type is a fairly objective process; it is clear from the wording of senators' questions if they are asking for "evidence" or interpretation of empirical evidence, as opposed to an opinion or purely factual information (e.g., Were you an attorney in 1980?) ${ }^{8}$ If one considers the distinction between ordinary and expert witnesses offered by Philips (1993), it follows that valued witnesses (in this context, males) need offer only their opinions to be judged worthy, whereas others may be asked to substantiate their claims. In addition, senators may utilize factual questions to reinforce the status of certain witnesses, particularly those regarded as insiders. For example, male witnesses may be asked simply to confirm their qualifications or educational degrees (for a similar argument, see Hurwitz, Miron, and Johnson 1992, 1928; Kathlene 1995b, 15).

Although a senator may ask certain types of questions, witnesses may vary in the type of response. As noted in the fourth hypothesis, male witnesses are expected to offer well-subtantiated testimony at higher rates than females. A sentence is coded as offering empirical evidence if it includes any reference to documents, legal cases, statistics, data, or studies.

There are other ways to determine whether a witness's effectiveness is being undermined. Repeated questioning can be a challenge to one's authority or knowledge (Tannen 1994b, 183). ${ }^{9}$ This may be combined with senators' insistence that a witness did not answer their question the first or second time. Such a process may be intended to provoke a certain answer or to indicate that a witness is "bad" or unresponsive and can safely be ignored. As with all other particular behaviors related to credibility, it is expected that women will be subjected to more repeated questioning than male witnesses.

Two final measurements of effectiveness are the frequency with which direct disagreements or challenges occur. Such behavior can be used by senators as a form of gatekeeping or by witnesses in an attempt to establish themselves as authorities. A sentence is coded as a disagreement if a speaker literally claims that

\footnotetext{
${ }^{7}$ For example, 4 full question periods out of 30 were counted twice; the remainder of interactive segments were partially recounted on a random basis. Word counts were done manually from copies of U.S. Senate transcripts.

${ }^{8}$ In cases where questions defied reliable categorization, they were excluded.

${ }^{9}$ Questions may be repeated for other reasons; for example, testimony may not be audible. However, procedural reasons are noted in the transcripts.
} 
another speaker is wrong, incorrect, or mistaken, or says, "I disagree." The category of "challenges" is admittedly the most subjective of the codes. When a speaker criticizes what another has said, albeit without using such words as "wrong" or "incorrect," the sentence is coded as including a challenge; specific examples are offered below in the findings. Additionally, Kathlene's recent analysis (1995b) details specific ways credibility is challenged, including a description of the witness's testimony as emotional or unreasonable, and the citation of other authorities to contradict a witness's testimony (15-19). Thus, specific codes were used to account for whether speakers described others in emotional or unreasonable terms or cited persons not present as counterauthorities.

\section{Findings}

\section{Hypothesis 1: access through participation.}

The first hypothesis posits that senators will dominate floor time. While the time utilized by each speaker cannot be measured, one proxy is the total number of words spoken by each senator and witness in each question period. With counts of individuals' word totals within each panel, the average number of words spoken per senator can be compared to the number spoken by the average witness. Data show that on every panel, except for panel 5 , the average witness says more than the average senator; thus, senators do not typically dominate witnesses. Evidence from panel 5 supports expectations about gender because senators do outspeak the female panel members. However, the overall evidence from word totals is mixed; the average female witness across all the panels speaks 1,075 words, the average male, 697. Furthermore, if we consider the individual question periods of each senator within a panel (e.g., only the interactions between Senator Biden and panel 5), we find no consistent gendered patterns. Senator Simpson held the floor for $66 \%$ of the time that he interacted with panel 5, but Senator Biden conceded $82 \%$ of floor time to the same women witnesses, and Senator Specter, $55 \%$. Based on quantity as an indicator of gatekeeping, neither witnesses in general nor female witnesses in particular were silenced by senators who controled the floor. ${ }^{10}$

A second measure of access is the proportion of time that each witness held the floor during his or her question periods with individual senators. While on average, witnesses may not be dominated by senators, gendered differences at the individual level may exist. Indeed, male witnesses were more likely to hold the floor for longer periods of time within their panels than were individual female witnesses; Mr. Williams spoke $48 \%$ of all words during his panel's question period, Mr. Gregg, 36\%, Mr. Rauh, 26\%, Mr. Douglas, 25\%. In contrast, the highest proportion of total words spoken by any woman on a given panel was

\footnotetext{
${ }^{10}$ The one exception to this pattern is Thurmond's total silencing of panel 5. In reaction to Thurmond's lack of questions, panel members later reported they had been made to feel powerless, and perceived they had been dismissed by him (Witt, Paget, and Matthews 1994, 67).
} 
$29 \%$ by Ms. Hernandez on panel 3, followed by Ms. Wattleton with $27 \%$, Ms. Michelman with $20 \%$, and Ms. Holtzman with $18 \%$. To be sure, there were both men and women who said relatively little on their respective panels (less than $10 \%$ of total words); but on average, male witnesses accounted for a higher percentage of the speaking on their panels than female witnesses.

Finally, to show whether particular panels receive relatively different treatment across senators, the average length of the entire question period for each panel was reviewed. ${ }^{11}$ Panel 1, consisting of one witness (Mr. Gregg of New Hampshire), had the shortest interactions, with an average of 156 words per speaker. Next was the all-male panel 6, with an average length of 386 words (see Table 1). The lengthiest discussions were conducted with the two all-female panels, followed by panel 3, which is two-thirds female. A related indicator of differential treatment is the degree to which a particular senator's question periods varied in length across panels. This measure shows that different treatment of panels is not a function of which senators interviewed the witnesses. Of the five senators who interacted with three or more of the six panels (Specter, Kennedy, Simpson, Biden, and Thurmond), four of them had their lengthiest interactions with one of the all-female panels. ${ }^{12}$ The one exception was Kennedy, whose longest discussion was with panel 3, which is two-thirds female. For four of the five senators, their second longest exchange was also with an all-female panel. The exception to this latter pattern is Senator Thurmond. While he questioned Ms. Michelman and Ms. Wattleton longer than any other panel he interviewed, his response to panel 5 was to ignore them altogether. He commented to the chair: "Mr. Chairman, we have a lovely group of ladies here. We thank you for your presence. I have no questions" (U.S. Congress 1991, 703).

With regard to access, measured by words spoken on the floor, the legislative process appears similar to that described by Kathlene, Clarke, and Fox (1991). Based on the fact that in raw numbers, the question periods for the all-female panels are the lengthiest, women's testimony is held up to lengthier questioning and, thus, higher scrutiny. Contrary to much of the literature, women witnesses are not silent relative to men, nor uniformly silenced. But considering the proportions of time that witnesses speak within panels, women are kept relatively quiet by senators in contrast to their male counterparts. As discussed below, this relatively different treatment is evidenced in other gendered patterns.

\footnotetext{
${ }^{11}$ These averages include all words spoken by both senators and witnesses. For example, the total number of words across the six question periods for panel 2 is 8,989 ; this number is divided by eight (the number of senators questioning the panel plus the number of witnesses) for an average of 1,124 . The very short question periods during which some senators chose to ask no questions are included; removing them does not change the relative ranking of the panels.

${ }^{12} \mathrm{~A}$ control for the political party labels of senators was introduced to see if Republicans tended to question witnesses at different rates than Democrats. However, the average questioning period for a senator of either party was equivalent $(1,000-1,100$ words).
} 


\section{Hypothesis 2: access and interruptions.}

In the hearings under consideration, all of the overlaps in conversation occurred between senators and witnesses across the 30 question periods were noted and analyzed to determine the purpose of the overlap. ${ }^{13}$ Out of a total of 76 overlaps in speaking by either senators or witnesses, 63 were made for the purpose of interrupting the speech of another so that the interrupter could speak or "take a turn." The remaining 13 overlaps were procedural (e.g., a witness was asked to speak louder), or for clarification or support.

Of the 63 interruptions, most (41) were made, as expected, by senators against witnesses; $82 \%$ (34) were directed at female witnesses, particularly on panels 2 and 5 . Of the 22 interruptions by witnesses of senators' speaking turns, $77 \%$ (17) were by women, contrary to what the literature leads one to expect. Still, proportionally, women did not interrupt male senators as frequently as they had their own speech interrupted; for example, Ms. Michelman and Ms. Wattleton were interrupted 15 times by Senators Heflin, Specter, Biden, Thurmond, or Simpson, but responded in kind only five times. In contrast, Mr. Williams (panel 6) responded to four of his five interruptions by immediately directing the same behavior at senators.

\section{Hypothesis 3: effectiveness and authority.}

There are many techniques that senators might use in order to contest the credibility or authority of any witness. As discussed above, it is hypothesized that the frequency of question type will vary by panel, with factual and opinion questions more often directed toward male witnesses than to female witnesses. Easier "factual" questions prompt short responses that require neither interpretation nor argument. Consider one such question that Senator Biden asked of Mr. Broderick, which had no follow-up: "Mr. Broderick, have you appeared before Judge Souter?" Mr. Broderick replied, "Yes, Mr. Chairman, I have tried cases in front of him when he was on the trial court, and I have argued in front of him in the New Hampshire Supreme Court" (U.S. Congress 1991, 554). Such an inquiry serves the positive purpose of reinforcing a witness's credentials. Similarly, "opinion" questions assume the witness's "expert" opinion is important and worth hearing. For example, on panel 4 (with three male witnesses and one female), Senator Simon asked:

But there is one other thing that we look for . . . in addition to being a champion of basic civil liberties. That is, some compassion, some understanding of those who are less fortunate. The testimony of Judge Souter, I have to say, was somewhat different in tone, more compassionate than the record I read. Any reflections, if I may ask each of you, of how Judge Souter would be as a Supreme Court Justice in this area? (U.S. Congress 1991, 560)

\footnotetext{
${ }^{13}$ Overlaps are indicated in the text by a dash (-). In passages below where I omitted text for the sake of brevity, omissions are marked by ellipses (. . .).
} 
Female witnesses are expected to encounter more analytic or empirical questioning, which requires them to establish their credibility and ability to reason. One example comes from an exchange between Senator Thurmond and the women on panel 2. Ms. Michelman and Ms. Wattleton explained that they opposed Judge Souter's nomination because he had not expressed a clear commitment to a right to privacy. The senator responded by asking, "What evidence do you have that he is against your position, anyway?" (U.S. Congress 1991, 393).

Data in Table 2 show a distinct, gendered pattern to the factual and empirical questioning pursued by the members of the Judiciary Committee. "Easier" factual questions were reserved for persons such as Mr. Gregg, Mr. Douglas, and Mr. Williams on panels 1, 4, and 6; the all-female panels (2 and 5) received virtually no such questions. The expectations regarding opinion questions are not as clearly confirmed, although panels 3 and 5 receive relatively fewer than other panels. Empirical questions that require interpretation or evidence were asked of all panels, but to different degress. Panels 2 and 3 experienced the highest rates of this type of questioning, at least once every 14 sentences.

As noted above, repeated questioning is another indication that senators feel they have not received adequate answers to their questions. Repeated questioning was seldom used; panel 2 , however, received a noticable amount. This is particularly attributable to Senator Thurmond's interactions with Ms. Michelman and Ms. Wattleton; he repeated one question, in slightly varied form, five times (U.S. Congress 1991, 392-93).

Two additional methods of undermining a witness's effectiveness are direct disagreements, or challenges. A sentence was coded as a disagreement insofar as a speaker literally disagreed or stated that a witness was wrong. For example, Senator Hatch and Ms. Holtzman discuss at length a legal case in which Judge Souter had been involved concerning an alleged rape and the admissibility of evidence at trial. In the past, Congresswoman Holtzman had been involved in writing rape-shield legislation, and thus would qualify as an "expert." At one point, Hatch responds to her critique of Souter's handling of a rape-shield law: "That is one side. I don't think you're right on it and I wanted to just point it out because we should both re-read the case" (U.S. Congress 1991, 705).

Challenges are differentiated from disagreements by the more subtle manner in which a senator is questioning a witness's authority. There may be challenges to an argument made, or to the manner in which a witness addresses a question. Challenges do not just result from policy disagreements; Senator Simpson states that he is pro-choice, yet still challenges female witnesses who testify on the issue. On September 18, Specter challenged the answer given by Ms. Michelman: "Those are very interesting comments, but they do not answer my question" (U.S. Congress 1991, 405).

Table 2 documents the number of disagreements and challenges by senators against each of the panels. Both panels 2 and 5, the all-female panels, were the 
TABLE 2

Senators' Statements and Gatekeeping, by Panel

\begin{tabular}{|c|c|c|c|c|c|c|c|c|c|c|c|c|}
\hline \multirow[t]{2}{*}{ Code } & \multicolumn{2}{|c|}{$\begin{array}{l}\text { Panel 1- } \\
\text { Mr. Gregg }\end{array}$} & \multicolumn{2}{|c|}{$\begin{array}{c}\text { Panel 2- } \\
\text { Ms. Michelman, } \\
\text { Ms. Wattleton }\end{array}$} & \multicolumn{2}{|c|}{$\begin{array}{c}\text { Panel 3- } \\
\text { Ms. Hernandez, } \\
\text { Mr. Rauh, } \\
\text { Ms. Bronk }\end{array}$} & \multicolumn{2}{|c|}{$\begin{array}{l}\text { Panel 4- } \\
\text { Mr. Douglas, } \\
\text { Mr. Broderick, } \\
\text { Mr. McAuliffe, } \\
\text { Ms. Cooper }\end{array}$} & \multicolumn{2}{|c|}{$\begin{array}{c}\text { Panel 5- } \\
\text { Ms. Holtzman, } \\
\text { Ms. Neuborne, } \\
\text { Ms. Allred, } \\
\text { Ms. Yard, } \\
\text { Ms. Smeal }\end{array}$} & \multicolumn{2}{|c|}{$\begin{array}{c}\text { Panel 6- } \\
\text { Mr. Williams, } \\
\text { Mr. Beck, } \\
\text { Mr. Barr }\end{array}$} \\
\hline & \multicolumn{2}{|c|}{4 Senators } & \multicolumn{2}{|c|}{6 Senators } & \multicolumn{2}{|c|}{3 Senators } & \multicolumn{2}{|c|}{8 Senators } & \multicolumn{2}{|c|}{5 Senators } & \multicolumn{2}{|c|}{5 Senators } \\
\hline \multicolumn{13}{|l|}{ Easier question type } \\
\hline Opinion question & 2 & 17.5 & 27 & 10 & 1 & 66 & $15(6)$ & 11 & 10 & 32 & 13 & 7.5 \\
\hline Factual question & 4 & 9 & 1 & 263 & $2(2)$ & 33 & $13(6)$ & 12 & 0 & 0 & 13 & 7.5 \\
\hline \multicolumn{13}{|c|}{ More difficult question type, and tests of authority } \\
\hline Empirical question & 1 & 35 & 19 & 14 & $12(7)$ & 5.5 & $3(1)$ & 54 & 9 & 36 & 4 & 24.5 \\
\hline Repeated question & 0 & 0 & 11 & 24 & 0 & 0 & 1 & 161 & 2 & 162 & 0 & 0 \\
\hline Disagreement & 0 & 0 & 7 & 38 & 0 & 0 & 0 & 0 & 13 & 25 & 0 & 0 \\
\hline Challenge & 0 & 0 & 56 & 5 & $2(2)$ & 33 & 0 & 0 & 59 & 5.5 & 4 & 24.5 \\
\hline Unreasonable, emotional & 0 & 0 & 7 & 38 & $2(2)$ & 33 & 0 & 0 & 18 & 18 & 0 & 0 \\
\hline Other authority & 1 & 35 & 9 & 29 & 0 & 0 & $2(1)$ & 80.5 & 9 & 36 & 1 & 98 \\
\hline
\end{tabular}

Note: For each panel, there are two columns of data in the table; the first contains the absolute number of times the senators who questioned the panel engaged in a type of discourse.

The second number is an indicator of the rate at which the behavior occurred, taking into account the total number of sentences spoken by the senators (e.g., the first two cells for panel 1 indicate that there were two opinion questions by the four senators, for a rate of one such question every 17.5 sentences). Lower positive rates indicate a higher frequency of occurrences.

The numbers in parentheses indicate the number of times such behavior was directed at a female witness for panels with both male and female witnesses. With regard to the type of questioning, questions directed at a female were not necessarily directed at a female exclusively. 
targets of most disagreements and challenges; there were no statements of disagreement by senators except in the context of all-female panels. Similarly, challenges were made by senators every 5 to 5.5 sentences on panels 2 and 5 ; the next most challenged panel was number 6 , with a rate of one challenge for approximately every 24 sentences. The only challenges on panel 3 occurred against female witnesses.

The last two measures of witnesses' authority are references made to what is "unreasonable," or to other authorities. Sentences were coded for any references to reasonableness or emotion. Such references by senators are indications that they view themselves as the authorities over what testimony is rational, and therefore worthy of their consideration. A clear example of such a reference occurs in Senator Simpson's discussion with Ms. Wattleton and Ms. Michelman. The witnesses have expressed doubt as to what Judge Souter's opinion is concerning the right to privacy. Senator Simpson responds: "But you talk about the majority of Americans who support the woman's right to choose and I'm one of those. So why this great inordinate fear of a single nominee to the Supreme Court who you really don't know where he stands on the issue? What is the basis of that inordinate, obsessive fear?" (U.S. Congress 1991, 399). As the data indicate, declarations of what is obsessive or reasonable are viewed as appropriate when talking to female witnesses, but never when interviewing any male witness.

Senators also can undermine a witness's testimony or opinion by invoking another person or organization that is viewed as an authority; this can occur in the context of a challenge. For example, Senator Hatch disputed Ms. Holtzman's ability to criticize Judge Souter's record:

Sen. Hatch: Now, Ms. Holtzman, I am concerned somewhat about your criticism of Judge Souter's opinion in the case State v. Colbath, and that was a unanimous decision of the New Hampshire Supreme Court. (U.S. Congress 1991, 704)

The implication seems to be that if members of the state court agreed, then Ms. Holtzman would not be in a position to criticize the decision. As Table 2 indicates, senators did not refer often to authorities, but did so most often in their discussions with women on panels 2 and 5; on panel 4, one of only two such references was directed at Ms. Cooper.

In considering the treatment of witnesses, it is clear that many confrontational exchanges occur between women and Republican senators. However, separate calculations of challenge rates for senators within each party does not account for gender differences. Republican senators do undermine the effectiveness of female witnesses more frequently than Democrats, but Democrats treated the same female witnesses relatively different, as well. For example, Ms. Michelman and Ms. Wattleton were challenged every four sentences by Republicans and every eight sentences by Democrats; this is the highest challenge rate for any panel among Republicans or Democrats. Panel 5 had the second-highest challenge rate within each party. Furthermore, the women on panel 3 (Ms. Bronk and 
Ms. Hernandez) were challenged twice by Senator Biden, the ranking Democrat, and not at all by the Republican side.

In addition to party labels, ideology might explain senators' behavior. Each senator was assigned an ideology rank of liberal, moderate, or conservative, based on their voting records. ${ }^{14}$ If ideology were of primary importance, one would expect liberals such as Senators Kennedy and Biden to behave similarly, regardless of the witness's sex. However, this is not the case. Senator Biden is the source of both challenges and language about what is reasonable in describing women's testimony on panel 3; the empirical questions all come from these two senators. In contrast, only one challenge is made and one empirical question asked by any liberal senator in questioning the men on the other panels. Senator Specter, a Republican moderate, is individually an assertive speaker; however, he is particularly so with female witnesses. He did not challenge or disagree with panel 4 at all. Panel 6 (all-male) was challenged every 23 sentences during their exchanges with Specter, but panels 2 and 5 every 6 to 10 sentences. Hence, despite ideology, gender remains important in legislative hearings.

\section{Hypothesis 4: witnesses' language and effectiveness.}

It was hypothesized that senators' inclinations to treat male witnesses as more effective than women is reinforced by men's greater use of rational, empirical testimony. The language used by witnesses is classified by panel in Table 3. Virtually all witnesses express opinions at about the same rate, every two to three sentences, with the exception of Mr. Gregg in panel 1. Mr. Gregg has a high rate of factual statements, undoubtedly in reaction to the higher rate of factual questions he received. Empirical evidence, however, is used most frequently by women on panels 2 and 5 , at a rate of once every three sentences. This is most remarkable from panel 5 , whose members used such evidence more frequently than requested by the senators. Therefore, the available evidence does not support the hypothesis that only male witnesses provide testimony that is classified as empirical.

\section{Hypothesis 5: the double bind.}

Hodgson and Pryor (1984) suggest that women ought to "devise strategies of communication designed to build . . . credibility." (p. 485). In a legislative hearing, therefore, they may utilize what is regarded as masculine language in order to compete; however, this paper hypothesized that they may meet with limited success in doing so. One example that supports this hypothesis concerns challenges. Paralleling the behavior of the senators, women on panels 2, 3, and 5 engage in what is considered assertive behavior, albeit at somewhat lower over-

\footnotetext{
${ }^{14}$ Data were obtained from The Almanac of American Politics, Washington, D.C., 1990. Any senator with a score from the Americans for Democratic Action (ADA) of $80 \%$ or above, and who opposed Bork's nomination was ranked liberal; any senator with a score from the American Conservative Union of $80 \%$ or above and who supported Bork was ranked a conservative. The remaining three senators were classified as moderates.
} 


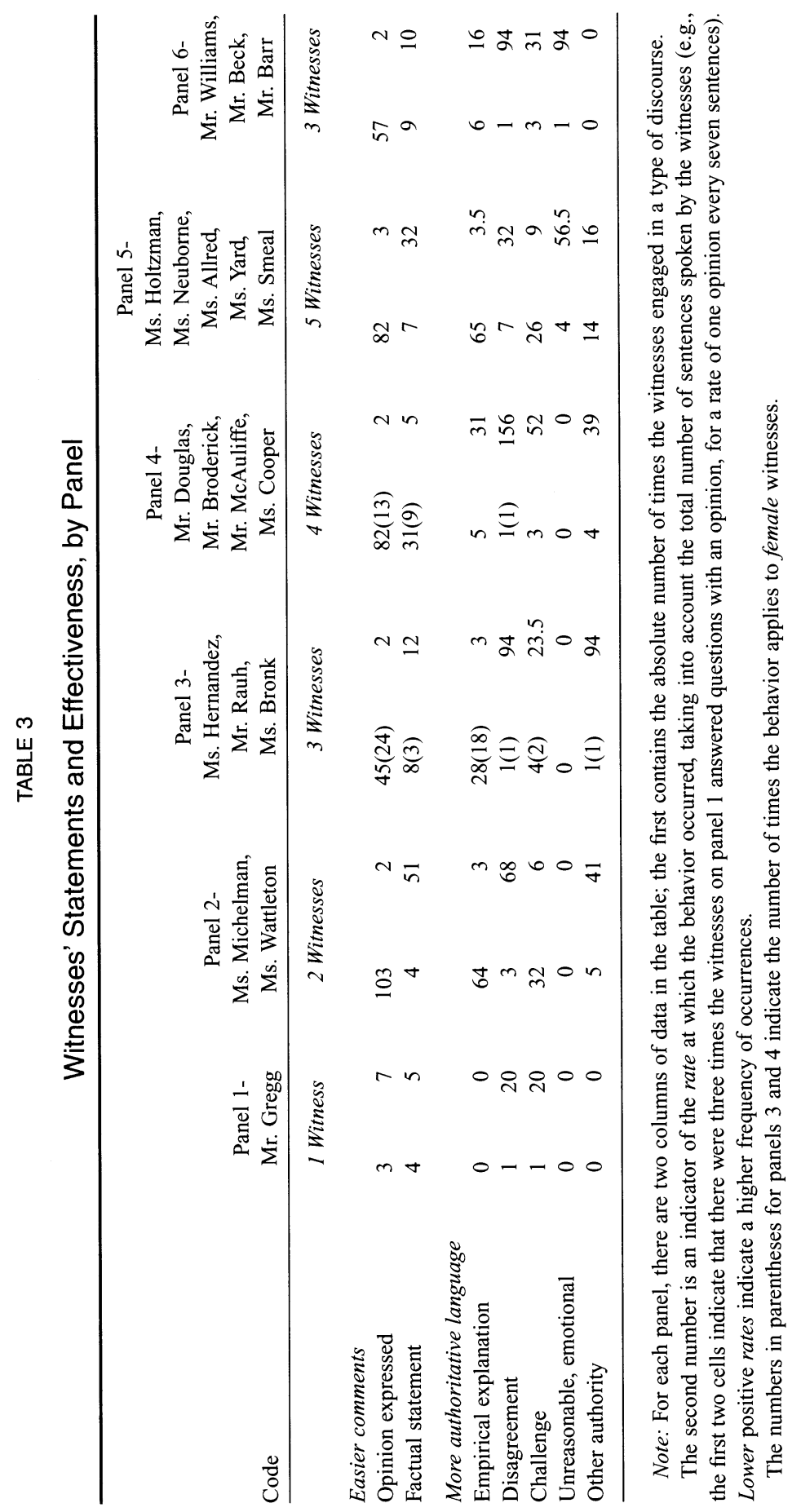


all rates than senators do. One reason they might temper the quantity of their responses is due to the differential reception that women receive for challenges, as opposed to the reactions received by male witnesses. During the hearings, Mr. McAuliffe and the other witnesses on panel 4 were asked by Senator Simon about David Souter's compassion for those less fortunate. In response, Mr. McAuliffe challenged the very fact that such a question would be asked: "I think you will understand - I hope - the frustration that we in New Hampshire sometimes feel when questions like that are asked, because it is the kind of question where you say, 'my God, how can anybody ask a question like that . . . ?" (U.S. Congress 1991, 561). The senator did not respond at all to that comment. In contrast, Ms. Michelman is challenged when she questions the relevance to her of an issue raised by Senator Specter.

Sen. Specter: Do you think that it is realistic, if we turn down Judge Souter, to find President Bush submitting to the Senate [someone] who will give you a flat commitment to uphold Roe v. Wade?

Ms. Michelman: . . . I think it is possible, and we cannot allow our views about this important right to go undiscussed, because we might get someone worse, as everyone keeps saying. The issue is what is before us now and what is at stake in this.

Sen. Specter: Those are very interesting comments, but they do not answer my question. . . . I just think it is not realistic to expect that if Judge Souter is turned down, we will find a nominee who will pass your test." (U.S. Congress 1991, 406-7)

In addition, there is a propensity for women, particularly on panel 5 , to cite other authorities in bolstering their arguments, perhaps in an effort to go beyond offering their own opinions. Although senators note titles and qualifications as indicators of authority, it is not sufficient for Ms. Yard to do so.

Sen. Simpson: Well, I would like to get back to page 10 of your testimony. You quote Professor Alan Dershowitz. . . . Could you please tell us what qualifications or experience Alan Dershowitz possesses ... . ?

Ms. Yard: Well, Alan Dershowitz is a respected professor of law-

Sen. Simpson: Of course he is.

Ms. Yard: at Harvard University.

Sen. Simpson: I didn't say he wasn't.

Ms. Yard: And I suspect he knows very well what he is writing. . . .

Sen. Simpson: But you see, what I'm saying is your statement is filled with flash words, and flash statements and that, somewhere that breaks down. (U.S. Congress 1991, 711)

On the same panel, Ms. Allred invokes the American Bar Association (ABA) to support her claim that Souter ought to have answered additional questions. Senator Simpson had earlier directly noted his confidence in the ABA and the "well-qualified" rating it gave to David Souter (U.S. Congress 1991, 711). As part of her testimony, Ms. Allred quotes from the "ABA Code of Judicial 
Conduct Canon 7(B)1(c)" and a Georgetown Journal of Ethics article stating that only judges who are up for election are prohibited from answering certain types of questions, such as questions concerning the right of privacy. When that fails to persuade Senator Simpson, Ms. Allred, an attorney, points out that Souter's testimony already violated the ABA rule that Senator Simpson views as binding on the judge.

Sen. Simpson: . . . you will find that a sitting judge cannot respond, cannot respond to questions about pending or impending legislation and I cite it for you right in the same document you have in your hand. . . .

Ms. Allred: Well, if that is the case, he has already done it, sir. He has done it talking about the War Powers Act. There is going to be a pending case before him on that. He has done it on the Lemon test, and on religious cases.

Sen. Simpson: Ms. Allred, he is a sitting judge. He is not a simple, you know, it is not a simple nomination. The man is a sitting judge and if you will look at the Code of Ethics that you have in your hand, you will see that he cannot respond to questions, ethically, of a pending or impending nature. Now, I don't know how clear-I have said that about four times since this started and everyone just shrugs and pooh-poohs that one. . . . (U.S. Congress 1991, 712)

Hence, although women are attempting to utilize what are viewed as masculine strategies, by challenging senators and using other authorities to back up their claims, senators often respond by offering counterarguments.

Finally, interruptions by women receive different responses from senators than are given to male witnesses. Mr. Rauh interrupted a question by Senator Kennedy, and was able to continue on with his own remarks for a full six sentences without any reaction from the senator. Similarly, Mr. Williams was able to interrupt Senator Specter successfully, even though Specter wanted him to address a different topic:

Mr. Williams: I think it was more than at most in those days, but-

Sen. Specter: Well, but that is a different-

Mr. Williams: I have not reached my conclusion, Senator.

Sen. Specter: OK. (U.S. Congress 1991, 775)

In contrast, Specter handles a comparable interruption by Ms. Michelman less amicably:

Ms. Michelman: Well, Senator, I would like to speak to your characterization of the polls. First of all-

Sen. Specter: Well, do that after you answer-

Ms. Michelman: I think you should vote against-

Sen. Specter: The pending question, if you would. (U.S. Congress 1991, 409)

To a large extent, Mr. Williams, the male witness who is interrupted the most, "retaliates" successfully by responding in kind to senators' behavior. Women do 
so less often, but when they use assertive behavior, they can be thwarted in their attempts. Thus, equal behavior from witnesses is not necessarily treated equally by the committee.

\section{Concluding Discussion}

A key question raised by this paper is whether women can compete on an equal footing with men within existing legislative institutions, given gender differences in language. Empirically, I find that women are not silent; they were $40 \%$ of invited witnesses at Souter's nomination hearings and were able to speak extensively as members of panels that were given considerable attention. However, females' access was limited because the average male witness had a higher proportion of floor time. Further, senators engaged in gatekeeping insofar as they interrupted women more frequently than men.

The effectiveness of women was limited by the fact that senators from both parties were more likely to undermine the authority of female witnesses than that of males, particularly through higher rates of empirical questions, disagreements, challenges, the citation of other authorities to contradict women's testimony, and the characterization of women's words as unreasonable. Equally important, however, is that female witnesses reciprocated with masculine language; despite extensive research that leads one to expect feminine communication, women used interruptions, challenges, empirical evidence, and the citation of other authorities. However, as hypothesized, such behavior was typically rebuffed or dismissed by senators. Consequently, it remains unclear what type of language women need to use in order to be treated as authoritative witnesses.

The implications of this research are limited by the scope of data presented thus far; additional legislative proceedings should be examined to explore further the impact of gender. Still, the available evidence leads to some tentative conclusions. First, historically, one way in which women, underrepresented among elected officials, have tried to make their political voices heard is through their appeals to Congress as outsiders (e.g., Kerber 1990; Kerber and De Hart 1995, 89). This study shows that as late as 1990 , members of gendered institutions still treat women differently, thereby perpetuating that outsider status. Second, the participation of a group's members is a necessary but not sufficient condition for fully effective representation in legislative struggles for power. Women have entered the competitive fray, but are not yet assumed to be the political equals of their male counterparts. Third, the interactions of elected officials and witnesses are important not only in the context of the decision processes of which they are a part, but because language is a reflection of the values and gendered assumptions of elected officials. Consequently, discourse analysis may be a valuable complement to other measures of legislators' opinions, such as roll call votes. Finally, this study of the U.S. Senate helps expand and confirm state legislative research that points to gender as a barrier to the effective political representation of women in predominantly masculine institutions. 
Manuscript submitted 15 July 1996

Final manuscript received 28 May 1997

\section{References}

Bachrach, Peter, and Aryeh Botwinick. 1992. Power and Empowerment: A Radical Theory of Participatory Democracy. Philadelphia: Temple University Press.

Carroll, Susan J. 1989. "Gender Politics and the Socializing Impact of the Women's Movement." In Political Learning in Adulthood: A Sourcebook of Theory and Research, ed. Roberta S. Sigel. Chicago: University of Chicago Press.

Case, Susan Schick. 1994. "Gender Differences in Comunication and Behaviour in Organizations." In Women In Management: Current Research Issues, ed. Marilyn J. Davidson and Ronald J. Burke. London: Paul Chapman Publishing.

Center for the American Woman and Politics (CAWP). 1996. National Information Bank on Women in Public Office, Eagleton Institute of Politics, Rutgers University Fact Sheets, August, November.

Chock, Phyllis Pease. 1995. "Ambiguity in Policy Discourse: Congressional Talk about Immigration.” Policy Sciences 28:165-84.

Costantini, Edmond. 1990. "Political Women and Political Ambition: Closing the Gender Gap." American Journal of Political Science 34:741-70.

D’Lugin, Victor F. 1993. "On Credibility: Differential Treatment of Women and Men in the Law." In Women in Potitics: Outsiders or Insiders?, ed. Lois Lovelace Duke. Englewood Cliffs, NJ: Prentice Hall.

Duerst-Lahti, Georgia, and Rita Mae Kelly. 1995. “On Governance, Leadership, and Gender.” In Gender Power, Leadership, and Governance, ed. Georgia Duerst-Lahti and Rita Mae Kelly. Ann Arbor: University of Michigan Press.

Edelsky, Carole. 1981. “Who's Got the Floor?" Language in Society 10:383-421.

Fairclough, Norman. 1989. Language and Power. London: Longman.

Ford, Lynne E., and Kathleen Dolan. 1996. "Contemporary Women State Legislators: A Diverse Group with Diverse Agendas." In Women in Politics: Outsiders or Insiders?, ed. Lois Lovelace Duke. Englewood Cliffs, NJ: Prentice Hall.

Hodgson, Shari, and Bert Pryor. 1984. "Sex Discrimination in the Courtroom: Attorney's Gender and Credibility." Psychological Reports 55:483-86.

Hooks, Bell. 1987. "Feminism: A Movement to End Sexist Oppression." In Feminism and Equality, ed. Anne Phillips. New York: New York University Press.

Huddy, Leonie. 1994. “The Political Significance of Voters' Gender Stereotypes." Research in Micropolitics 4:169-93.

Hurwitz, Steven D., Murray S. Miron, and Blair T. Johnson. 1992. "Source Credibility and the Language of Expert Testimony.” Journal of Applied Social Psychology 22:1909-39.

Jamieson, Kathleen Hall. 1995. Beyond the Double Bind: Women and Leadership. New York: Oxford University Press.

Kathlene, Lyn. 1994. "Power and Influence in State Legislative Policymaking: The Interaction of Gender and Position in Committee Hearing Debates." American Political Science Review 88:560-76.

Kathlene, Lyn. 1995a. "Alternative Views of Crime: Legislative Policymaking in Gendered Terms." Journal of Politics 57: 696-723.

Kathlene, Lyn. 1995b. "Incredible Words!: Gender, Power, and the Social Construction of Legitimacy in the Policy Making Process." Presented at the annual meeting of the Western Political Science Association, Portland, OR.

Kathlene, Lyn, Susan E. Clarke, and Barbara A. Fox. 1991. "Ways Women Politicians are Making a Difference." In Gender and Policymaking: Studies of Women in Office, ed. Debra L. Dodson, Brunswick, NJ: CAWP, Eagleton Institute of Politics, Rutgers University. 
Kelly, Rita Mae, and Georgia Duerst-Lahti. 1995. "The Study of Gender Power and Its Link to Governance and Leadership." In Gender Power, Leadership, and Governance, ed. Georgia Duerst-Lahti and Rita Mae Kelly. Ann Arbor: University of Michigan Press.

Kenney, Sally J. 1996. "New Research on Gendered Political Institutions." Political Research Quarterly 49:445-66.

Kerber, Linda. 1990. "'I Have Don . . . much to Carrey on the Warr': Women and the Shaping of Republican Ideology after the American Revolution." In Women and Politics in the Age of the American Revolution, ed. Harriet B. Applewhite and Darline G. Levy. Ann Arbor: University of Michigan Press.

Kerber, Linda, and Jane Sherron De Hart, eds. 1995. Women's America: Refocusing the Past. 4th ed. New York: Oxford University Press.

Kollock, Peter, Philip Blumstein, and Pepper Schwartz. 1985. "Sex and Power in Interaction: Conversational Privileges and Duties." American Sociological Review 50:34-46.

Luttrell, Wendy. 1995. “'The Teachers, They All Had Their Pets': Concepts of Gender, Knowledge, and Power." In Rethinking the Political: Gender, Resistance, and the State, ed. Barbara Laslett, Johanna Brenner, and Yesim Arat. Chicago: University of Chicago Press.

MacKinnon, Catharine A. 1993. Only Words. Cambridge: Harvard University Press.'

Mueller, Carol. 1991. "The Gender Gap and Women's Political Influence." Annals of the American Academy of Political and Social Science 515:23-37.

Pearson, Judy Cornelia, Richard L. West, and Lynn H. Turner. 1995. Gender and Communication. 3d ed. Madison, WI: Brown \& Benchmark.

Philips, Susan U. 1993. "Evidentiary Standards for American Trials: Just the Facts." In Responsibility and Evidence in Oral Discourse, ed. Jane H. Hill and Judith T. Irvine. Cambridge: Cambridge University Press.

Sapiro, Virginia. 1991. "Gender Politics, Gendered Politics: The State of the Field." In Political Science: Looking to the Future, ed. William Crotty. Evanston, IL: Northwestern University Press.

Smith-Lovin, Lynn, and Charles Brody. 1989. "Interruptions in Group Discussions: The Effects of Gender and Group Composition." American Sociological Review 54:424-35.

Stewart, Lea P., and Dianne Clarke-Kudless. 1993. "Communication in Corporate Settings." In Women \& Men Communicating, ed. Laurie P. Arliss and Deborah J. Borisoff. Fort Worth: Harcourt Brace Jovanovich.

Tannen, Deborah. 1990. You Just Don't Understand: Women and Men in Conversation. New York: Ballantine Books.

Tannen, Deborah. 1994a. Gender and Discourse. New York: Oxford University Press.

Tannen, Deborah. 1994b. Talking from 9 to 5: How Women's and Men's Conversational Styles Affect Who Gets Heard, Who Gets Credit, and What Gets Done at Work. New York: William Morrow and Company.

Thomas, Sue. 1994. How Women Legislate. New York: Oxford University Press.

U.S. Congress. Senate. Committee on the Judiciary. 1991. The Nomination of David H. Souter to be Associate Justice of the Supreme Court of the United States. 101st Cong., 2d sess., September 13, 14 , and 17-19.

Witt, Linda, Karen M. Paget, and Glenna Matthews. 1994. Running as a Woman: Gender and Power in American Politics. New York: The Free Press.

Laura R. Winsky Mattei is assistant professor of political science, State University of New York at Buffalo, Buffalo, NY 14260. 